\title{
VIAGEM À DIÁSPORA SAARAUI
}

\author{
Berenice Bento ${ }^{1}$
}

\begin{abstract}
"E quando chega a hora da partida, a mãe sai com o filho ou a filha fora da raima [a tenda saaraui] e pede que fique descalce e caminhe alguns passos. De suas pegadas pinça um pouco de areia e a guarda no nó de sua melhfa [veste típica da mulher saarauia]. Quando o filho parte, ela espalhará parte desta areia pelos quatro pontos cardiais da raima e o resto deixará repousar em um cofre até a volta do filho ou da filha."
\end{abstract}

(Limam Boisha, poeta saaraui)

Quantas vezes as mães saarauias repetiram este rito de despedida? Quantas vezes as mães viram suas filhas e filhos partirem ao longo dos 44 anos em que o povo saaraui luta para voltar para suas casas, hoje sob ocupação colonial marroquina? As histórias coloniais podem ser narradas a partir de datas e eventos reconhecidas pelo mundo. No caso saaraui, o ano 1975 é o marco. Enquanto guerrilheiros da Frente Polisário (representante política do povo saaraui) combatiam contra os colonizadores espanhóis, as Forças Armadas marroquinas se preparavam para invadir o território. "O Saara Ocidental nos pertence!", gritavam os marroquinos. A Mauritânia também reivindicava o território como seu. É neste mesmo ano, no dia 16 de outubro, que a Corte Internacional de Justiça (CIJ) de Haia declarou que o Saara Ocidental não pertencia nem ao Marrocos tampouco à Mauritânia. Esta decisão foi fundamental para o reconhecimento internacional do direito do povo saaraui ao seu território.

O rei de Marrocos, Hassan II, no entanto, não reconheceu a soberania saaraui e, com um discurso nacionalista, organizou e estimulou a invasão do Saara Ocidental, a chamada "Marcha Verde" (as aspas são para denunciar o engodo da história oficial marroquina. A "marcha" está inscrita no projeto marroquino de genocídio do povo saaraui). O exército da Frente Polisário agora tinha que combater a invasão de Marrocos ao Norte e da Mauritânia ao sul. A Mauritânia, após sucessivas derrotas, retirou-se em 1979, mas deixou sua marca de destruição, conforme veremos mais adiante.

\footnotetext{
${ }^{1}$ Universidade de Brasília, Brasil. Email: berenice.bento1@gmail.com

ORCID id: https://orcid.org/0000-0001-5839-0097
} 
A Espanha saiu do território, mas antes, em 14 de novembro de 1975, assinou em Madri o Acordo Tripartite, em que o ditador espanhol Francisco Franco (que morreria seis dias depois) entregava o Saara Ocidental ao Marrocos e à Mauritânia. O Acordo que vai de encontro à posição da Corte Internacional de Justiça (CIJ) de Haia e já nasceu sem nenhuma legitimidade política. Conforme se comenta, a Espanha fez uma colonização ruim e uma descolonização pior. Sobre a posição da Espanha, uma ativista espanhola da causa saaraui comentou em um encontro informal que tivemos em Sevilha: "A Espanha abandonou o povo saaraui. Abandonou... E devemos seguir sendo responsáveis por tudo que acontece com ele". Não estou convencida de que a imagem de "abandono" seja a melhor, porque o Acordo de Madri foi uma demonstração clara de que a Espanha seguiria tendo posições privilegiadas na exploração das riquezas naturais saarauis, com destaque para a pesca, as reservas de petróleo e as minas de fosfato ${ }^{2}$. No dia 27 de fevereiro de 1976, os membros da Frente Polisário proclamaram a República Árabe Saaraui Democrática (RASD).

Os saarauis, com medo da repressão marroquina, começaram a fugir de suas casas rumo ao deserto. Muitos dos que permaneceram no Saara Ocidental desapareceram e outros passaram anos nas prisões secretas do Reino de Marrocos ${ }^{3}$. O cessar-fogo com Marrocos só seria assinado em 1991, depois de 15 anos de guerra.

Para frear as vitórias da Frente Polisário, o Marrocos construiu um muro de 2.200 quilômetros, o que equivale, mais ou menos, à distância entre Lisboa e Amsterdam. A cada $5 \mathrm{~km}$ do muro, há bases de controle militar, envolvendo $110 \mathrm{mil}$ soldados. Esta imensa barreira dividiu a população do Saara Ocidental. Atualmente, uma parte está no lado ocidental e outra do lado oriental, nas Zonas Liberadas, controladas pela Frente Polisário. Enquanto isso, a população que fugiu se abrigou em uma parte do deserto pertencente à Argélia e deu início à construção dos Campos de Refugiados (vide mapa). E como os saarauis que têm familiares separados pelo muro fazem para se encontrarem? Tanto os saarauis que vivem sob a ocupação colonial marroquina quanto os que estão vivendo nos Campos de Refugiados podem passar apenas pela fronteira da Mauritânia, ao sul. Os voos são agenciados pela ONU, mas esses encontros são poucos, apenas cinco famílias por vez.

\footnotetext{
${ }^{2}$ Ver documentário Um Fio de Esperança: Independência ou Guerra no Saara Ocidental.

${ }^{3}$ Sobre a situação dos presos políticos em Marrocos, ver: http://afapredesa.blogspot.com/
} 


\section{¿DÓNDE ESTAMOS?}

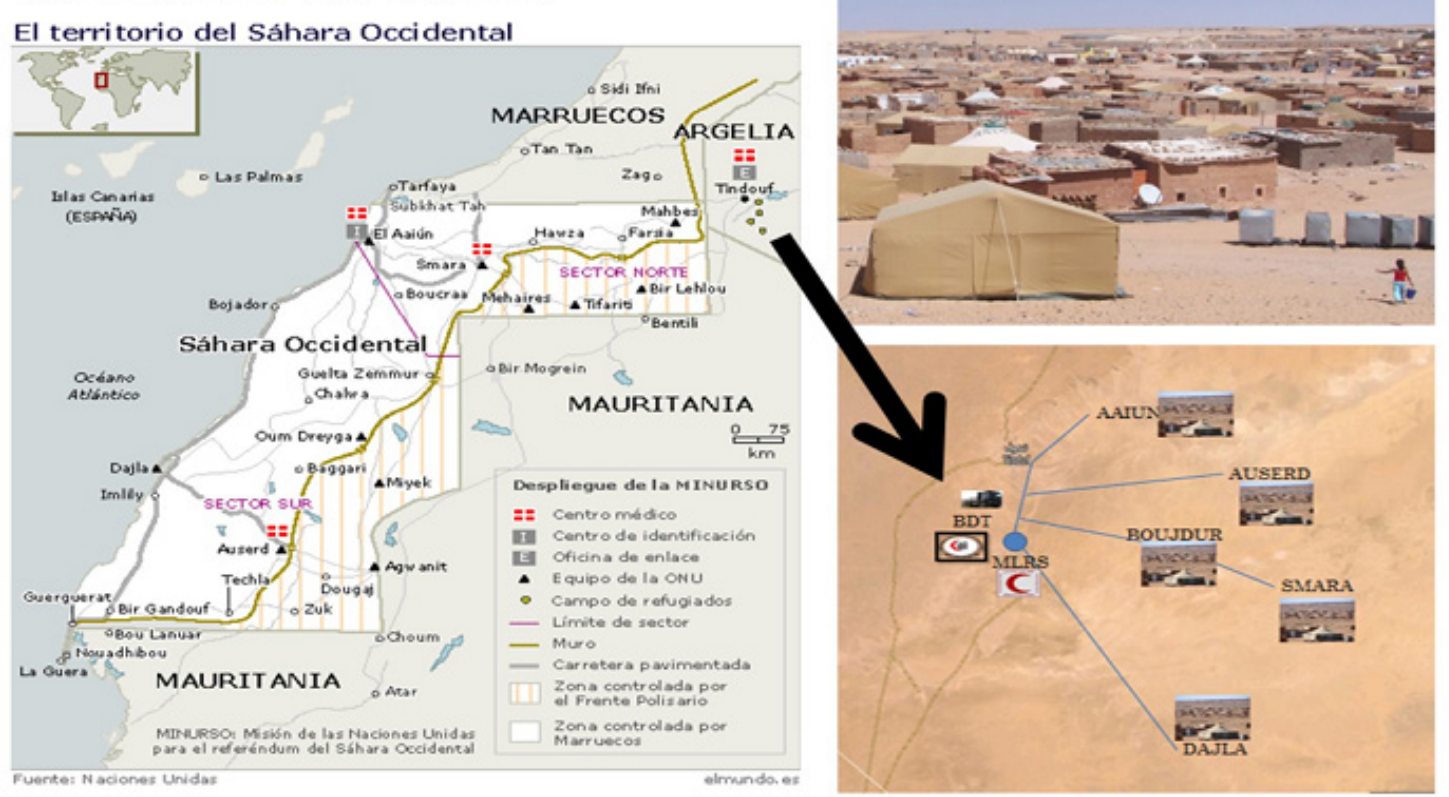

Em 1988, o Marrocos e a Frente Polisário assinaram o Settlement Plan (Plano de Ajuste), que previa, originalmente, um período de transição mediado pela ONU. Agora, a cena do conflito não era mais o da trincheira armada, mas a diplomática. Em 1991, foi criada a Missão das Nações Unidas para o Referendo do Saara Ocidental (MINURSO), que tinha como objetivo principal supervisionar o referendo no qual os saarauis iriam decidir pela anexação ao Reino de Marrocos ou pela organização de um Estado soberano. Inicialmente, Marrocos concordou com a realização do referendo, mas retrocedeu e continuou a avançar em sua política genocida. Já se passaram 29 anos e a MINURSO tem fracassado sucessivamente na implementação do objetivo para o qual foi criada.

O território do Saara Ocidental continua dividido e seu povo está espalhado entre a ocupação colonial marroquina, os campos de refugiados no deserto da Argélia e por vários países do mundo. Pode-se perguntar: Ora, se há um território que foi liberado pela Frente Polisário, por que os saarauis que estão nos Campos de Refugiados, em solo pertencente à Argélia, não ocupam suas terras? Porque ali, nas proximidades do muro, encontram-se cerca 10 milhões de minas subterrâneas espalhadas por Marrocos, o que a torna esta região muito perigosa para se viver (Africana Studio, 2018). 


\section{Na casa da família Buyema - Campo de Refugiados Bojador/Tindouf (Argélia)}

As narrativas históricas feitas em grossas pinceladas não nos deixam acessar as biografias de sujeitos e de suas famílias que tiveram suas vidas alteradas pela colonização espanhola, pelas guerras contra a invasão da Mauritânia e, ainda hoje, pela ocupação colonial marroquina. A colonização espanhola, seguida da limpeza étnica implementada por Marrocos, transformou-se em fato social total na vida de cada saaraui. Não é possível fazer uma narrativa do eu sem se referir a esta marca histórica. $\mathrm{Na}$ dimensão micro, na vida cotidiana dos sujeitos concretos, a violência colonial marroquina, por um lado, e a omissão da ONU, por outro, é humanizada, tem rosto. A tragédia humana acontece ali, nos poros da sociedade, na precariedade material dos Campos de Refugiados, nas perdas e lutos, nos não lutos provocados pela ausência dos corpos dos seres amados ${ }^{4}$.

Durante sete dias (entre os dias 22 e 29 de fevereiro de 2020), convivi com a família Buyema, no Campo de Refugiados Bojador. Antes de chegar ao campo, fiz um itinerário por Portugal, Espanha e Argélia para conversar com saarauis, filhos e filhas que entregaram para suas mães os grãos de areia antes de partirem. Em Lisboa, Granada, Córdoba, Sevilha, as conversas sempre vinham com conselhos e advertências ao saberem que o ponto final de minha viagem seria nos Campos. Isabel Lourenço, ativista dos Direitos Humanos e pesquisadora portuguesa da questão saaraui, preocupou-se com minha saúde, com orientações sobre ética e etiqueta que devem ser observadas ao compartilhar os espaços nas famílias saarauis, além de intermediar contatos. Em Granada, conheci o seu amigo, Ali Squered, que vive na Espanha com Hayta (sua esposa) e seus dois filhos. Por algumas horas conversamos sobre a vida nos Campos, diáspora e sobre o projeto de retorno para seu país. O som que acompanhou nossas conversas foi o da preparação do chá. Por horas, em movimentos precisos, sua esposa preparava os três chás, uma das marcas da identidade saaraui. Depois de algumas horas de conversa, chás, biscoitos, sucos, levantei-me para iniciar as despedidas. Ainda fiquei mais algumas horas. Lembrei-me das palavras de Isabel: "não existe povo mais hospitaleiro que o saaraui". Conheci histórias de famílias saarauis que fazem pequenos empréstimos que lhes possibilitem comprar alguma coisa de comer e beber às visitas. Como é possível que pessoas vivendo em condições de precariedade e vulnerabilidades

\footnotetext{
${ }^{4}$ Dados sobre os mortos e desaparecidos pelas forças armadas marroquinas, ver: http://afapredesa.blogspot.com/
} 
absolutas possam ser movidas por uma relacionalidade ética em que o bem-estar do outro torna-se central?

As conversas com saarauis que estão na diáspora foram, de certa forma, movidas pela minha própria angústia para entender como é possível viver sem o reconhecimento internacional de pertencimento a um Estado-nação. Talvez possa parecer estranho, mas ter uma identidade nacional reconhecida internacionalmente me coloca numa posição de privilégio. Nem sempre pensamos sobre isso porque ter um pertencimento nacional é algo naturalizado. É como se a organização política das pessoas em Estados sempre tivesse existido. Falas dos saarauis vivendo no exílio me fizeram olhar o meu passaporte como um papel mágico, que autoriza meu corpo a transitar por regiões do mundo. Certamente não vale muito ter o passaporte sem as condições materiais, mas esta é a primeira condição para transitar entre as fronteiras nacionais legalmente: pertencer a um Estado-nação. Lembro-me de que, quando eu estava no aeroporto de Tel Aviv, nas viagens que fiz à Palestina, eu sabia que podia ser deportada, que o Estado de Israel, se soubesse do meu ativismo pela Palestina, não me deixaria entrar. Caso eu fosse deportada, no entanto, como tantos/as outros/as já foram por denunciarem os crimes contra a humanidade cometidos sucessivamente por Israel contra o povo palestino, eu sabia que tinha um lugar para onde voltar. Eles me colocariam em um avião e, em poucas horas, eu estaria no Brasil. Para onde um palestino é deportado? Para que país um saaraui volta? Squered me disse:

Estamos desterrados. É difícil explicar esta sensação de saber que você tem uma casa, tem um lugar e não pode voltar. Não sei explicar muito bem. Sinto que não tenho lugar. Eu moro aqui em Granada. Tratam bem a mim e à minha família. Mas aqui não é nosso lugar. (Granada, 15/02/2020)

Enquanto estava em Bojador, uma das filhas da senhora Buyema recebeu com alegria o marido que, atualmente, vive na Espanha trabalhando em um restaurante. Passaram-se um ano e dez dias desde que a filha e o filho viram o pai pela última vez. Naquelas noites, ela estava especialmente bonita e jovial. A maquiagem, as henas sofisticadas nos pés e nas mãos, a fragrância, a melhfa elegante, eram sinais de que ela estava em festa. O marido, enquanto preparava o chá, me contava como era dura a vida longe da família. Com salário mínimo espanhol que recebe, tem que ajudar seu pai (que vive na Espanha), mandar dinheiro para a família e pagar suas despesas. E família aqui não se restringe à esposa e aos filhos, mas inclui a mãe e outros parentes que também 
não têm nenhum trabalho remunerado nos Campos. Desta forma, ele nem sempre consegue economizar para comprar a passagem para visitar a família. Ele e quatro filhos da família Buyema fazem parte da cifra dos milhões de refugiados espalhados pelo mundo. É como se fosse a diáspora dentro da diáspora. Nos Campos não há trabalho remunerado, o que provoca um segundo deslocamento. $\mathrm{O}$ total de pessoas deslocadas no mundo passa de 70 milhões. Desse total, quase 26 milhões são considerados refugiados pelos padrões do Acnur (Alto Comissariado das Nações Unidas para os Refugiados). Na Europa, são mais de 400 centros de detenção nos quais milhares de pessoas esperam anos para terem seus pedidos de refúgio, asilo, ou pedido de proteção internacional avaliados ${ }^{5}$. Vivemos um momento na história dos Estados-nação onde nunca se presenciou tantas pessoas sem-Estado. Este talvez seja um dos efeitos mais nefasto da invenção moderna dos Estadosnação: a produção reiterada do sujeito sem-Estado.

Em Argel, conheci um jovem saaraui que se diz incapaz de ficar longe dos amigos, família e da futura esposa - todos moram nos Campos. A cada três meses vai para sua raima e daí tira a certeza de que "ninguém ganha numa guerra, ninguém. Mas não estão deixando outra alternativa para nós". Disse-me isso enquanto visitávamos o Memorial dos Mártires em Argel. Certamente, diante das armas, da instalação de uma sala de tortura que reproduzia os métodos adotados pelos franceses contra o povo argelino, ele via cenas que não estavam ao alcance de minha experiência. Seus parentes foram para guerra contra Marrocos e muitos não voltaram.

A senhora Buyema tem sete filhos: quatro mulheres e três homens. $\mathrm{O}$ filho mais velho, aos 10 anos, foi para Cuba estudar. Formou-se em medicina e só voltou a reencontrar os pais aos 23 anos. O segundo vive em Madri; o terceiro agora vive em Tindouf (cidade argelina mais próxima aos Campos) com a esposa. Das quatro filhas, uma vive com o marido na Espanha. Quando partiu, há seis anos, deixou a filha mais velha aos cuidados das irmãs e dos pais.

Se 1975 é um marco para a história do povo saaraui, naquela casa, aquele ano produziu suas marcas na lembrança e nos corpos. As primeiras batalhas contra a invasão da Mauritânia deixaram o Senhor Buyema brutalmente ferido. Naquele momento, já tinha dois filhos e sua esposa. Com medo de futuros ataques tanto da Mauritânia quanto de Marrocos, foi para o deserto com outras famílias. As raimas foram montadas para esperar o retorno para suas casas que se imaginava próximo. Este foi o primeiro

\footnotetext{
${ }^{5}$ Ver: http://www.anafe.org/
} 
momento da grande divisão das famílias. A Mauritânia foi derrotada pela Frente Polisário, mas a família não voltou. Ao contrário, a distância entre as famílias aumentou com a construção do muro por Marrocos.

Enquanto a luta seguia contra Marrocos, as famílias foram organizando a vida coletiva nos campos. Filhas e filhos nasceram sob tendas, famílias se formaram e se dividiram, às tendas somaram-se casas de alvenaria. A ajuda humanitária chegou, escolas e hospitais foram precariamente sendo construídos. Entre a ajuda de organismos internacionais e religiosos (com destaque para a Crescente Vermelha) e a solidariedade fundamental de Cuba e da Venezuela, a vida foi fazendo-se. O tempo no Campo, porém, não é o mesmo daquele que organiza a cotidianidade no âmbito do Estado-nação. $O$ tempo da espera para voltar para casa regula a vida nos Campos. A ajuda humanitária pode não chegar, a comida escassear, a água (de péssima qualidade) pode matar. $\mathrm{O}$ calor do deserto e as doenças daí derivadas são fatos que não permitem que se esqueça da natureza provisória do "estar". É como se ninguém habitasse aquele lugar, mas estivesse lá. Uso o verbo "habitar" no sentido filosófico, de ser e sentir-se parte. Habitamos a língua que falamos, porque ela nos constitui, nos oferece senso de pertencimento. A língua é a forma simbólica de nossas digitais no mundo. Os lugares são como línguas. Manter-se vivo e cuidar dos seres amados, enquanto o tempo da volta para casa não chega, é um gesto revolucionário.

A jovem Dahduh, uma das milhares de saarauis que nasceu nos Campos, enquanto me mostrava o enorme galpão onde são guardados os mantimentos básicos que são distribuídos às famílias refugiadas, pontua: "nossa causa é política, não é humanitária. Estes galpões já estiveram mais cheios. As doações estão diminuindo ano após ano". Ela sabe que não se pode ter uma nação mantida à base de caridade. Qual a diferença entre a razão humanitária e o reconhecimento político? Se o leite, a lentilha, a farinha e outros produtos doados pelos organismos internacionais não vierem acompanhados do reconhecimento de que Marrocos precisa pagar por seus crimes e devolver os territórios roubados, o que se está fazendo é tão somente a administração continuada da precariedade da vida.

Estávamos na raima. Sr. Buyema seguia contando-me seu engajamento na luta pela autodeterminação de seu povo e por sua própria vida naquele ano de 1975 . Na grande raima, no entanto, estavam outras pessoas, com outras conversas. É como se houvesse paredes invisíveis. Eram muitos sons ao redor: o som do chuá-chuá do chá, as crianças que entravam e saíam, a mãe que conversava com as filhas, visitas que 
chegavam. Não tenho certeza, mas acredito que o povo saaraui está nos Campos e habita suas raimas, estas tendas que se constituem em lugares-citação de um tempo de liberdade identificado com a existência beduína.

Eu me esforçava para não perder nenhuma palavra do Sr. Buyema. Sua filha me avisou: "ele fala espanhol, mas não fala muito". Depois, suas filhas, curiosas para saber como tinha sido a conversa, comentaram: "Ficamos surpresas. Ele não é de falar muito". Enquanto conversávamos, ninguém chegou perto de nós. Tudo que aquele senhor me contava parece fantástico, algo próximo a uma narrativa épica: como ele sobreviveu? Devidos aos ferimentos, perdeu parte do cérebro e os movimentos do braço direito. Foram anos de hospital em hospital lutando para sobreviver.

Conta o poeta Boisha que uma das tarefas mais difíceis para o povo saaraui é dar uma notícia ruim, principalmente, quando envolve morte. Para diminuir a dor, há um rito verbal em que o emissário afirma: "Não é a você a quem eu conto, eu conto à solidão”. E ao escutar esta frase o destinatário já sabe que o trágico aconteceu. Quantas vezes a senhora Buyema não sentiu o coração apertar ao pensar que a notícia se dirigia a ela, principalmente nos seis primeiros meses em que ficou sem notícias do seu marido?

Como a família Buyema tornou-se possível? Todos os/as sete filhos/as sobreviveram. Aos poucos, fui compreendendo que a solidariedade e a cooperação entre vizinhos foram fundamentais na história daquela família. $\mathrm{Na}$ primeira fase de organização dos Campos, todos comiam a mesma comida, ajudavam-se mutuamente a montar as tendas, a cuidar dos/as filhos/as uns dos outros. Mas há um componente fundamental em toda saga de resistência saaraui, em geral, e dos Buyema, em particular: "sem a força de minha mulher eu não estaria aqui", me disse o Sr. Buyema. A construção das casas de alvenaria, das raimas, a organização social e política, tudo passou e passa pelas mãos das mulheres.

Eu já tinha escutado outras vezes a importância da mulher da sociedade saaraui (Martín, 2016; Lusuardi; Silocchi, 2019). Para Ali Squered, em nossa conversa em Granada, no entanto, engana-se quem pensa que este protagonismo começou a ser ocupado devido às mazelas impostas pelos colonialismos espanhol e marroquino. Segundo ele, as mulheres sempre tiveram um lugar central entre os saarauis.

Ao longo dos meus dias nos Campos, cumpri uma agenda de entrevistas e encontros, entre eles, com representantes da União Nacional de Mulheres Saarauias, com a Ministra da Cooperação (Senhora Fatma Mehdi), a Presidente do Departamento de Formação (Senhora Raboub Barka), com a Governadora da Província de Auserd 
(Senhora Mariam Salek Hmada). A importância das mulheres na organização dos Campos já é reconhecida, mas como acontecem as relações de gênero no âmbito privado? As mulheres saarauis sofrem violência de gênero? Há dados sobre feminicídio? Estas questões, antes de tudo, revelam-me. O Brasil é um dos países mais perigosos do mundo para as mulheres e esta realidade me constitui, daí a centralidade que a violência de gênero contra as mulheres teve em minhas conversas com autoridades saarauias. A ministra Fatma Mehdi afirmou: "Somos uma sociedade muçulmana, por isso não é possível ou admissível a violência contra as mulheres". Voltei a pautar o tema na entrevista com a governadora Mariam Salek Hmada: "somos a única sociedade no mundo onde não há um único caso de violência doméstica. Nenhum. Nem agressão, nem assassinato". Os desafios, apontou Salek Hmada, são de outra ordem: "Estamos fazendo um trabalho com as mães e as meninas para que se valorizem, para que não deixem a sensação de fracasso lhes dominar. Para isso, precisamos ter mais educação voltada para igualdade de gênero, para transformar as mentalidades”.

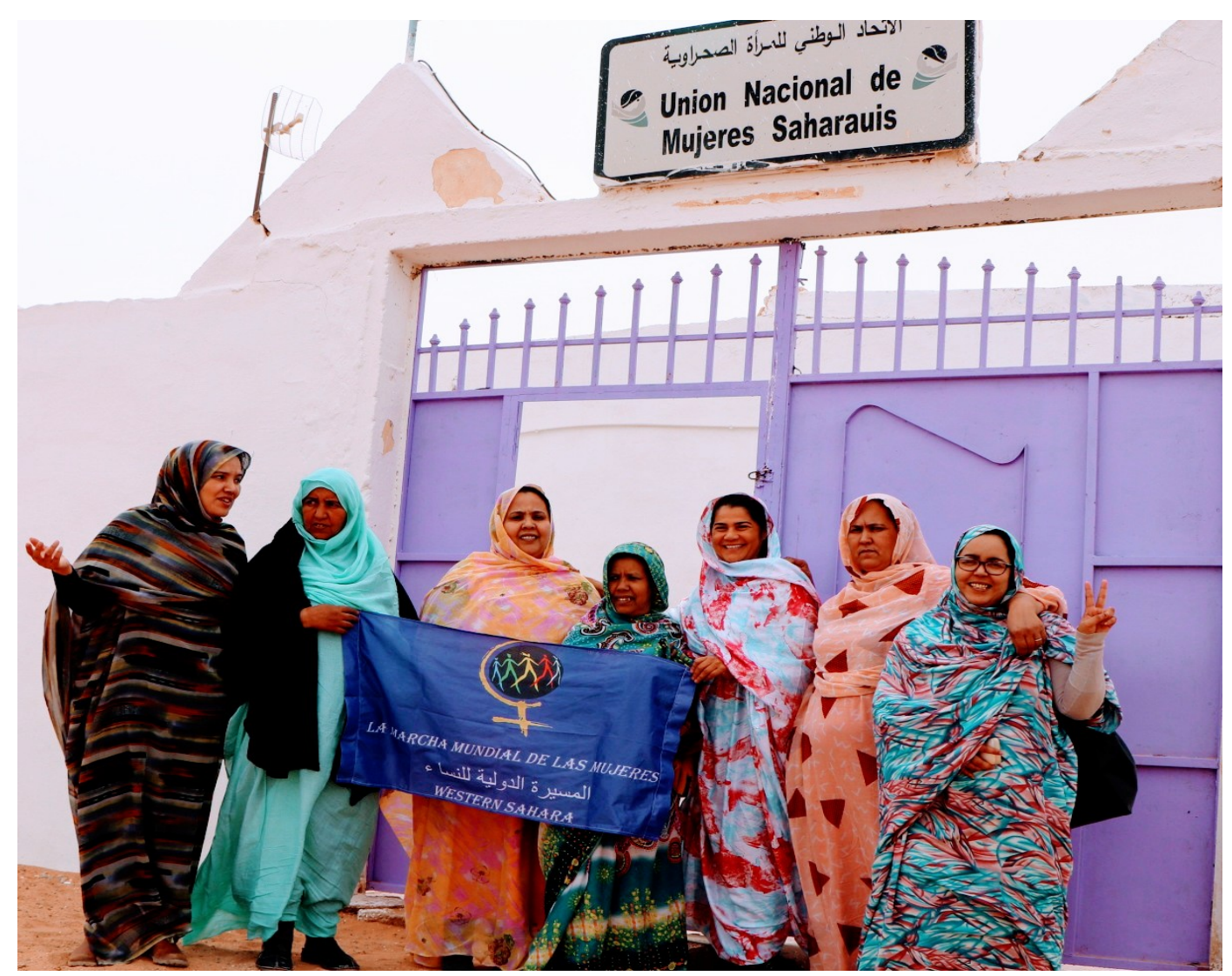

Legenda: Reunião com representantes da União Nacional das Mulheres Saarauias. 
Talvez possa parecer incomum eu referir-me à "governadora", "ministra" quando estou escrevendo sobre Campos de Refugiados. Internamente há uma sólida auto-organização política, o que diferencia os Campos de Refugiados Saarauis de outros. Cada um dos Campos funciona como província (wilayas) e os cinco maiores elegem um/uma governador/a. Atualmente, dos cinco governadores, duas são mulheres (província de Bojador e de Auserd). Cada província é dividida em distritos (dairas). Cada distrito, por sua vez, subdivide-se em bairros. Os nomes das províncias são os mesmos de cidades do Saara Ocidental: Laayoune, Auserd, Smara, Dakhla, Rabouni (Campo onde fica a sede administrativa), e, mais recentemente, Bojador. Esta estratégia de nomeação é um mecanismo para aproximar simbolicamente as populações separadas pelo muro e para fazer com que os mais jovens tenham um sentimento de identificação com seu povo que vive sob a ocupação colonial marroquina. O parlamento é formado por representantes eleitos diretamente pelos moradores das províncias.

Esta organização política singular não pode produzir uma ilusão de que estamos diante de uma situação política regular. São Campos de Refugiados, em terras argelinas. Para conseguir entrar nos Campos, a primeira etapa de minha viagem foi conseguir uma carta-convite, com justificativa, da Frente Polisário. Com esta carta, fiz a solicitação de visto na Embaixada da Argélia. De Argel até Tindouf, segui as normas de segurança para qualquer pessoa que queira visitar a Argélia. No entanto, de Tindouf até os Campos, havia o controle da Frente Polisário e da segurança argelina. Os elementos estruturais que definem um Campo estão presentes, com destaque para a dependência total para sobrevivência, dos mecanismos de controle de entrada/saída e a noção de provisoriedade (Fassin, 2016). Desta forma, a autonomia política é relativa, portanto, frágil, e os recursos materiais escassos. No entanto, o fato de serem Campos habitados exclusivamente por saarauis, diferente de outros Campos que recebem refugiados de várias nacionalidades, termina por produzir níveis de coesão social próprias ao imaginário de Nação.

Tenho a inferência de que a importância da organização política e administrativa deve ser observada para além da estrutura do Campo. Os saarauis voltarão para seu território. A experiência política de negociação, de construção coletiva dos organismos de decisão, terá efeitos no momento do retorno para suas terras e de estruturação efetiva da República Árabe Saaraui Democrática.

A presença internacional nos Campos é marcante. Da doação de sacos plásticos, pela Itália, para empacotar o cuscuz produzido artesanalmente pelas mulheres, às 
bibliotecas Bubisher, financiadas por grupos espanhóis, nota-se uma complexa rede de apoio que, ao mesmo tempo, revela o nível de dependência. Mas as ausências também são notadas. Durante os dias em que estive em Bojador, a única presença da ONU visível foi a de um caminhão velho de água, com a sigla UNHCR (United Nations High Commisioner for Refugees) enferrujada.

A queixa da posição e das (não)ações da ONU, via a MINURSO, também é notada nos territórios ocupados por Marrocos. A esperança de uma presença mais enfática da ONU para contribuir na resolução do conflito transformou-se em poeira.

\begin{abstract}
Os funcionários da ONU (MINURSO) assistem de seus carrões aos saarauis serem agredidos pela polícia de Marrocos. Veem que os marroquinos estão ocupando nossas casas, explorando nossas riquezas. O que fazem? Qual o interesse destes funcionários em fazer qualquer coisa para resolver o drama político do povo saaraui? Eles são, afinal, a razão última de seus gordos salários em euros, (Bojador, 24/02/2020)
\end{abstract}

desabafou um jovem saaraui. A situação dos saarauis que vivem sob a ocupação caracteriza-se pela perseguição, prisões ilegais, tortura e com restrições ao acesso aos bens necessários fundamentais (Lourenço, 2017; 2018; 2019).

\title{
Os grãos de areia querem voltar para a terra
}

Se eu já conhecia a centralidade das mulheres na sociedade saaraui, me surpreendi com a centralidade das pessoas velhas que chegam a ser veneradas por sua experiência e sabedoria. Poucas vezes fiquei no mesmo espaço que os donos da casa, mas quando ia cumprimentá-los havia um tipo de áurea de respeitabilidade que fazia com que o meu corpo se inclinasse em posição de reverência quase mecanicamente e o meu "Salam aleikum" era pronunciado quase em sussurro. Escutei pessoas saarauis comentando o modo desrespeitoso como as sociedades ocidentais lidam com os velhos. Para eles, não há razões aceitáveis para se retirar os donos de suas casas e transferi-los para outro espaço. Ponderei com Ali Squered que muitas vezes não há condições para se cuidar bem dos pais quando há enfermidades. Ele me respondeu que por anos cuidou de sua mãe que tinha Alzheimer. "Este é nosso dever." A caçula da família Buyema comentou: "Eu passei uns meses de férias na casa de uma família espanhola. Eles trabalham muito para pagar uma residência para a avó. Eu não entendo como eles 
podem fazer aquilo". Ela refere-se ao Programa Férias em $\mathrm{Paz}^{6}$, em que algumas crianças saarauias, devido às condições climáticas insuportáveis no deserto, principalmente no verão, passam as férias na casa de famílias espanholas.

O Programa recebe críticas porque, para alguns, se trata de uma "perversidade receber jovens que vivem em condições subumanas e depois de algumas semanas devolvê-los a mesma precariedade", conforme analisou uma ativista dos direitos humanos espanhola. Inicialmente, compartilhei desta indignação, no entanto, ao conversar com várias pessoas nos Campos que participaram do Programa me reposicionei. O reconhecimento da importância de ter conhecido outros lugares, pessoas e cultura é seguindo de uma reflexão sobre a impossibilidade de viver naquela sociedade. As diferenças na construção e organização dos espaços das casas, a culinária e forma de compartilhar a comida à mesa, a relação com as crianças e com os velhos desenham diferenças que fazem a filha caçula dos Buyema afirmar: "eu não moraria na Espanha. Eu tive muita saudade de minha família e de minha casa". Nenhuma das pessoas que entrevistei demonstrou deslumbramento com o modo de vida espanhol.

O ethos saaraui se impõe nos gestos cotidianos: no chá, na comida compartilhada no mesmo prato, no orgulho em servir carne de camelo sobre um perfumado cuscuz, na música, na abertura para o/a visitante. Em uma das noites, as mulheres da casa e algumas convidadas dançavam. Em movimentos suaves com as mãos e firmes com os pés, elas dançaram e, ao mesmo tempo, admiravam a habilidade de Vadiya, em uma performance no Youtube a que assistíamos ${ }^{7}$. Assim, entre chá, dança, música, as horas voavam. Naquela noite de dança, fomos dormir às duas da manhã e às oito da manhã já estávamos sentadas no chão, ao redor de uma mesinha redonda, tomando nosso café para iniciarmos mais um dia de trabalho.

Cumpri uma agenda intensa de entrevistas com autoridades saarauis. Mas foi na casa, nos rituais banais do dia a dia que a força da conversa que tive com o diretor da Escola de Cinema $^{8}$ se encarnou. Para ele, o cinema se constitui como uma arma poderosa de visibilização de um povo que tem sua existência negada sistematicamente por Marrocos. "Afinal, nossa luta é, antes de tudo, e principalmente, cultural”. As digitais, ou as assinaturas culturais estão na fala da jovem Buyema quando diz: "eu não moraria na Espanha".

\footnotetext{
${ }^{6} \mathrm{http}: / / \mathrm{www}$.arapaz.org/vacaciones-en-paz/

${ }^{7} \mathrm{https}: / /$ www.youtube.com/watch?v=t_qNbY9LIWE

${ }^{8} \mathrm{http}: / / \mathrm{www}$. escueladecinedelsahara.org/
} 
A agenda de trabalho teve seus momentos de improviso. "Berenice, você quer entrar na biblioteca?” Os rapazes já limpavam seus braços e rostos com areia para fazer suas preces voltadas para Meca enquanto o sol começava a se por. A sensação que eu tinha, antes de entrar nos lugares, era a de que não teria muito que fazer, porque a estética vazia das estradas de terra produzia a sensação do nada. Meu olhar perdia-se em um punhado de construções precárias, tendas, na presença insistente das moscas, alguns currais improvisados para poucas cabras e naqueles simulacros de ruas delimitados por pneus velhos. O que perturbava este cenário homogeneizado pela cor da areia do deserto e pela estética da precariedade material eram as mulheres com suas vestes coloridas. Aqueles corpos e suas cores, de certa forma, humanizavam aquele espaço onde, inicialmente, pode-se acreditar que seja impossível para qualquer ser vivo sobreviver.

Entramos na biblioteca. Em uma sala de cerca de 20 metros quadrados, crianças faziam manualidades, falavam ao mesmo tempo, e outras disputavam a atenção do professor. Alguns visitantes estrangeiros conversavam. A Bubisher explodia de vida, cores, sons ${ }^{9}$. Um dos projetos da biblioteca é a escrita de livros por criança. Foi neste espaço que conheci a obra o poeta Limam Boisha. Eu estava enganada. A estética do nada esconde (ou protege) uma cultura pulsante. O povo saaraui faz o improvável acontecer.

No improviso da agenda, conheci a Escola de Ensino Médio Sueilem Ahmed, em Auserd. O diretor da escola, talvez já prevendo que poderia surgir alguma pergunta sobre o uso do véu, se antecipou: “O véu não é obrigatório, mas se as estudantes usarem, pedimos que sigam as cores do dia. Apenas para ficar mais bonito". Era o dia do véu azul. A sala de aula era muito simples, mas as paredes estavam coloridas com trabalhos dos/as estudantes.

A agitação da casa, as conversas em hassanía (a versão saaraui do árabe), a cozinha em atividade intensa, as visitas de parentes, amigos e vizinhos contrastavam com o vazio das ruas. As horas eram preenchidas por afazeres e presenças. Acompanhei várias conversas de amigas que visitaram a casa. Algumas vezes, eu pensava que as jovens estavam furiosas umas com as outras. A voz de uma elevava-se, a da outra também. Os argumentos pareciam não ter fim. Eu não entendia nada e tampouco pedia para traduzirem. Em um desses encontros, o tema era o divórcio de uma mulher do Campo. As opiniões de quem estava certo, se a esposa ou marido, eram antagônicas.

\footnotetext{
${ }^{9}$ http://www.bubisher.org/
} 
Enquanto a disputa argumentativa seguia, o marido de uma delas preparava o chá e acompanhava com o olhar a conversa. Já era quase uma da manhã.

As crianças da casa riam, com gargalhadas dobradas, ao observar meu esforço tentando pronunciar seus nomes em árabe. Para minha vergonha, elas aprenderam muito rapidamente o meu. Eu acordava com seus risos e com meu nome em suas bocas. Olhava-as inventando brincadeiras com as pedras do deserto. Será que elas também terão que deixar suas famílias, deslocar-se para outro lugar para garantir a sobrevivência? Será que terão que seguir fazendo a diáspora da diáspora? Tenho como hipótese que a vida dos saarauis que vivem nos Campos de Refugiados só tem se tornado possível porque eles têm uma identidade cultural enraizada, um senso de justiça inabalável, confiam em suas lideranças políticas, e uma eficaz organização política interna. E, principalmente, eles têm as raimas, lugares em que habitam. Acredito, contudo, que as mães já estão esgotadas das despedidas, de espalhar grãos de areias pelas tendas e da espera sem fim.

\section{REFERÊNCIAS}

AFAPREDESA. Asociación de familiares de presos e desaparecidos saharauis. Disponível em: http://afapredesa.blogspot.com/.

ASSOCIATION NATIONALE D'ASSISTANCE AUX FRONTIIÈRES POUR LES ÉTRANGERS. Disponível em: http://www.anafe.org/.

AFRICANA STUDIA. Saara Ocidental - as políticas do impasse. Revista Internacional de Estudos Africanos, Porto, Universidade do Porto/FLUP, n. 29, 1. Semestre 2018.

BOISHA, Limam. Ritos de jaima. Zaragoza: Ediciones Bubisher, 2019.

ESCUELA de cine Sahara. Disponível em: http://www.escueladecinedelsahara.org/.

FASSIN, Didier. La razón humanitaria: una historia moral del tempo presente. Buenos Aires: Prometeo Libros, 2016. 
FOUR days in Occupied Western Sahara - a rare look inside Africa's Last Colony. Democracy Now. Disponível em: https://www.youtube.com/watch?v=smg97ib_yfM.

LOURENÇO, Isabel. Saharawi Children and Students under occupation, WP/CEAUP/\#2019/1, 2019. Disponível em: http://www.africanos.eu/index.php/en/.

- Saharawi Political prisoners - The impact of detention on families Psychological, social and economical Impacts on the families of the prisoners, 2018. Disponível em: https:/www.academia.edu/37155690/Saharawi_Political_prisoners_The_impact_of_detention_on_families_Psychological_social_and_economical_Impacts _on_the_families_of_the_prisoners.

. Sahara Occidental Mujeres bajo ocupación, 2017. Disponível em: https://www.academia.edu/37155671/Sahara_Occidental_Mujeres_bajo_ocupaci\%C3\% B3n.

LUSUARDI, Caterina; SILOCCHI, Roberta. Ecco, sono venuti a prendermi: resistenza e tenerezza dele donne sharawi. San Martino: San Martino, 2019.

MARTÍN, Rocío Medina. Mujeres Saharauis: três tuizas para la memoria de la resistência. Sevilla: Aconcagua Libros, 2016.

SUZIN, Giovana Moraes; DAUDÉN, Laura. Nem paz, nem guerra: três décadas de conflito no Saara Ocidental. Rio de Janeiro: Tinta Negra, 2011.

UM fio de esperança: independência ou guerra no Saara Ocidental. Direção: Renatho Costa e Rodrigo Duque Estrada. Documentário. Disponível em: https://www.youtube.com/watch?v=KY1bfenG3Js\&vl=pt.

Recebido: $30 / 04 / 2020$

Aprovado: 15/07/2020 